DOI https://doi.org/10.18551/rjoas.2017-05.01

\title{
ENSURING OF FOOD SECURITY IN RUSSIAN FEDERATION
}

\author{
Silanteva E.S. \\ Lomonosov Moscow State University, Moscow, Russia \\ E-mail: the best kat@mail.ru
}

\begin{abstract}
The study provides information on approaches to the problem of ensuring of Food security in the country. The levels and the models of Food security and the theoretical aspects of national Food security are investigated in this research. It was found that there are five levels of Food security that go from total autonomy in the food supply to the total dependence from the exporters. The models also represent the ideas from two different approaches to the economy: Protectionism and Free Market. The strategic goal of Food security is to provide the population of the country with the safe agricultural and fish products. International specialization and cooperation contributes to the achievement of food supply and demand balance that helps to prevent food crises and ensure Food security at the international level. Stability of domestic production, as well as the availability of the necessary resources is the guarantee for achieving of national Food security. This study provides evidence that the competitiveness of national business in food market should be increased to develop Economy and to ensure Food security. This problem could be solved due to the mobilization of competitive advantages of domestic companies. For Russian food and trade companies main competitive advantages are: natural resources, unoccupied territories, production facilities, cheap labor force and cooperation with other Russian organizations and international business. In conclusion it was mentioned that to enhance the food manufacturers' competitive potential it is necessary to create a fair trading environment that ensures Food security for the population and allows Russian manufacturers of different sizes to grow.
\end{abstract}

\section{KEY WORDS}

Food security, food manufacturers, food suppliers, wholesale companies, trade, retail, competitive advantages, competitiveness, competition, national business, market, resources, institutions.

The problem of ensuring of Food security is being updated in the Russian Federation in connection with the aggravation of the political situation and the introduction of a food embargo on the products of main importers. In economic theory, the concept of «Food security» includes the task of guaranteeing for each citizen the physical and economic accessibility to food in volumes not less than rational consumption norms, as well as solving the problem of the successful functioning of a national business of various sizes. In this regard, it is important to consider increasing the competitiveness of national companies as an instrument for ensuring the country's Food security.

There are various definitions of Food security fixed in official documents. The most accepted definition is provided by FAO experts that define Food security as a state of the economy, in which every person has physical, social and economic access to a sufficient number of safe and nutritious foods that meet his dietary needs (FAO, 2015). This definition of Food security affects four important aspects of human life: the physical availability of food, economic accessibility, health security and the balance of nutrition.

It is considered that the amount of food import should be no more than $20 \%$ of the average annual volume of consumption of vital food products in the country, their own safe import volume can be set for different products (Biktimirova, 2002). Otherwise the import will serve not as an addition to domestic production but, on the contrary, will lead to its decline. Thus, national Food security is considered to be achieved by providing to consumers the basic domestic food products that can be produced in the territory of a given country, taking 
into account its natural and climatic conditions, at a rate of not less than $80 \%$ of annual consumption, taking into account the traditional features, socio-demographic structure of the population and in accordance with physiological norms of nutrition.

Levels of food security. There are five levels of ensuring the Food security in the country (Korbut, 2002).

The first level: of basic foodstuffs, when domestic demand is less than the national production of agricultural goods and there is the possibility of exporting food.

The second level: production of only necessary for domestic consumption of food, usually by limiting overproduction in order to stabilize food prices and the break-even of agricultural producers.

The third level: assumes a situation of optimal food imports, not exceeding $20 \%$ of the annual consumption of basic food.

Fourth level: a threshold level of food dependence is allocated, when about $30 \%$ of consumed food depends on international supplies. In this situation, there is already a threat to Food security.

Fifth level: the state's food dependence on other countries of the world, when external forces in the territory of the dependent state can initiate a food catastrophe - hunger and social unrest.

In this regard, in order to increase the level of food self-sufficiency of the country, the comprehensive support should be provided for domestic food manufacturers. In order to prevent possible external threats, the countries should create a state reserve fund, monitor world food production, and diversify the structure of agricultural exports.

Achievement of global Food security also requires unified, coordinated and carefully measured actions of Governments, transnational companies and international organizations. At the present stage of the globalization of the world economy, national Food security is of paramount importance in this regard. Developing the State policy in the field of Food security, the Government should consider the combination of factors. Expert assessment of the country's opportunities for food self-sufficiency should be provided on the basis of analyses of all resources, economic, scientific and technical potential of the country and the influence of climatic changes on the food manufacturing.

Models of food security. Modern models of ensuring Food security can be conditionally divided into two types.

The first type is the insignificant state support of domestic food manufacturers and the minimum tariff and non-tariff barriers to imported food.

The second type is the substantial support of agriculture by the State through subsidies, production quotas, tariff measures and other methods of trade regulation. The State control over the functioning of agriculture and the food industry in this case is traced in the whole mechanism of interaction between state, food manufacturers, trade companies and consumers.

The best example of the second type model of Food security is the European Union, which regards agriculture in terms of multifunctionality at the legislative level. The term «multifunctionality of agriculture» reflects the fundamental relationships between agriculture and ecological, political and socio-economic situation in the country, as well as the preservation of the culture and traditions of each nation within the framework of Western European integration. This idea is reflected in the general agricultural policy of the EU and is the "core of the agrarian protectionism» of the European Union and its Food security.

There are three principles of the EU Common Agricultural Policy (Moiseev, 2003).

The principle of Common Market. It implies the unhindered movement of food products, the application of uniform prices for them, the unification of national legislative norms for regulation of domestic food manufacturing and marketing, including sanitary, phytosanitary and veterinary norms, as well as supranational supervision of observance of the principles of free competition.

The principle of Financial Solidarity: it presupposes the financial provision of the common agricultural policy from the single budget of the European Union. Stabilizing 
domestic prices for vital agricultural products contributes to ensuring physical and economic access to Food security.

Principle of Export Support: existing in EU «agricultural subsidies» help to support domestic food manufacturers and reduce the cost of manufactured food to the world level. For each exported unit of a product, a European farmer receives compensation from the European Agricultural Guarantee Fund.

Thus, multilateral measures of the EU Common Agricultural Policy contribute to achieving Food security within the Union. The protection of the agricultural and food sectors of the EU, on the one hand, helps protect and develop the domestic food market and achieve the high level of Food security; on the other hand, it can adversely affect the agriculture of third countries, endangering their Food security.

Components of Food security in the Russian Federation. In the food sphere of Russian Federation, the notion of «ensuring of Food security» involves the problems of import share reducing in the food market and guaranteeing of physical and economic accessibility to food products in volumes not less than rational consumption norms for each citizen. The Food security Doctrine of the Russian Federation states that the Food security is one of the main directions for ensuring the national security of the country in the medium term. Food security is one of the most important components of the demographic policy of the Government, a prerequisite for the implementation of the strategic national priority quality of life of Russian citizens by guaranteeing high life standards.

One of the indicators that help to assess the state of Food security in the country is the share of domestic food and fishery manufacturing in the total volume of commodity resources of the domestic market of corresponding products. In accordance with the Food security Doctrine of the Russian Federation, the minimum level of own grain production should be at least $95 \%$, sugar - at least $80 \%$, meat and meat products (in terms of meat) - $85 \%$, milk and dairy products (in terms of milk) - not less than $90 \%$, fish products - not less than $80 \%$, potatoes - not less than 95\%, salt of food - not less than $85 \%$ (Food Security Doctrine, 2010).

Thus, it is advisable to subsidize the sectors that are strategically important for ensuring the country's Food security: the production and processing of grain, the production and processing of meat and meat products, the production and processing of milk and dairy products, the production and processing of fish products, the production of potatoes, and the production of salt.

The Food security of the Russian Federation can be conditionally divided into the three components: the ability to produce a sufficient amount of food within the country, the protection of food industry from external and internal shocks and the ability of the state to monitor the quality of food received by the population.

Long-term Food security. International practice shows that long-term Food security can be ensured only on the basis of domestic production within the country. The current state of Russian agriculture is a direct result of the liberal policies of the 1990s. At that time, state support for agriculture practically disappeared. This happened due to the cheap food subsidized by the exporting countries in the amount of $20-50 \%$ of its cost. To date, the Government of Russia is facing the urgent task of pursuing a policy of import substitution and the development of the food sector in the Russian Federation.

The food sphere of Russia should be protected from unforeseen negative phenomena. The shock events include the following: a sharp rise in prices for agricultural products; a sharp increase in the cost of agricultural production, in particular, due to the increase in prices for fuel, fertilizers and machinery; low yield in the country or in the world; restriction or termination of food imports by exporting countries.

Clear numerical safety criteria should be identified in a number of areas of protection against negative phenomena. For example, according to experts of the FAO, one of the main indicators of Food security of the state is the size of grain reserve remaining before harvesting of the next crop. A reserve corresponding to $20 \%$ of its annual consumption is considered safe. The main grain reserve in Russia is about $18-20$ million tons or $30-35 \%$ of annual consumption (FAO, 2009). 
Food availability. The availability of food products consists of the prevalence of trade places and the ability of the population to buy products at existing prices.

Today, the prevalence of retail outlets is a significant factor promoting the availability of food products for Russia as a whole, with the exception of remote small settlements, where food trade is not commercially attractive. At those territories exists the "socially significant» small and medium-sized enterprises.

In a market economy, the price / quality ratio is crucial for most of consumers. Wholesale and food retailers do not differentiate by the origin of the goods; they tend to maximize their profit that is a natural market behavior.

Thus, the availability of domestic food products in comparison with imported food products depends, first of all, on the competitiveness of the national manufacturers.

One of the tools to ensure Food security in the Russian food market is to increase the competitiveness of national manufacturers.

Russian enterprises in the food market along the entire value chain, agricultural and food manufacturers, wholesale and retail enterprises have a certain competitive advantages that can be estimated from the standpoint of the current market, resource and institutional theories. A company can increase its competitiveness by implementing the full range of competitive advantages.

The largest contribution to Market Theory of competitive advantages of a company was provided by M. Porter (Porter, 2011). This theory is based on the assumption that a company needs to occupy an advantageous position in the industry in order to ensure its competitiveness in relation to competitors. In accordance with the concept of Market Positioning, the Russian firm should choose that field of activity, where the result of its functioning is not only valuable to consumers, but also helps the company to position itself in the most efficient manner in competitive environment.

Most contribution to the development of Resource Theory of competitive advantages was made by E. Penrose (Penrose, 2009), C. Prahald (Prahald, 1990) and G. Hamel (Hamel, 1990), R. Grant (Grant, 2011). This theory proclaims the existing complex of unique resources and capabilities of the company as the priority direction of development of the company. In the short term, the competitiveness of a firm depends on the price and consumer characteristics of its key products, but in the context of global competition in the long term, the competitiveness is based on the ability of the company to create key competencies, on the basis of which unforeseen products are born, at lower costs and faster than competitors.

According to the Institutional Theory of competitive advantages (Katkalo, 2006), economic behavior and economic choice of an organization are determined not only by resource opportunities, but also have an institutional and social nature. The Institutional approach is based on the notion that competition in the modern world carries an essential element of cooperation, manifested in the activities of companies within the network entities. In today's economy, to create additional competitive advantages, the company must effectively integrate into the environment and network relationships with other firms, the state and civil society actors.

The main Market competitive advantage of Russian business in the food market is the existence of the phenomenon of territorial asymmetry in providing the population with food. Resource competitive advantages are unoccupied production facilities, cheap labor of sufficiently skilled workers and consumer loyalty to Russian brands. Institutional competitive advantages include the cooperation of Russian producers among themselves and within industries, as well as the cooperation of Russian organizations with international business.

Conclusion. The problem of ensuring Food security was overviewed in various economic theories. It was revealed that in order to ensure Food security in the country, it is necessary to increase the competitiveness of the Russian food business. Analysis of the Russian food market showed that Russian companies have a competitive potential and have certain market, resource and institutional competitive advantages. In this regard, it is important to increase the competitiveness of national food manufacturers, as well as create a 
fair trading environment that ensures Food security for the population and allows Russian manufacturers of different sizes to develop.

\section{REFERENCES}

1. Biktimirova Z. Security in the Concept of Human Development. (2002), Public sciences and modern time, 6, pp. 135-142.

2. Doctrine of Food security (2010) Consultant Plus [Informatsionno-pravovaia sistema]. URL: http://www.consultant.ru/document/cons_doc_LAW_96953/

3. Food and Agricultural Commodities Production. FAOSTAT [Official site]. URL: http://faostat.fao.org/site/339/default.aspx (accessed: 24.04.2017).

4. Grant R. Strategic development. (2011) Saint Petersburg: Piter

5. International Trade Statistics 2013. World Trade Organization [Official Site]. URL: https://www.wto.org/English/res_e/statis_e/its2013_e/its13_toc_e.htm

6. Katkalo V., Evolution of the theory of Strategic management, (2006), Saint Petersburg, Publishing house SPBGU.

7. Kleiner G. Resursnaia teoriia sistemnoi organizatsii ekonomiki. Rossiiskii zhurnal menedzhmenta, 2011, t. 4, no 3, pp. 3-28.

8. Methodological Issues and Preliminary Results. Food and Agricultural Organization of the United Nations [Official site]. URL: http://www.fao.org/docrep/016/ap527e/ap527e.pdf (accessed: 24.04.2017).

9. Penrose E., Pitelis C. The Theory of the Growth of the Firm. Oxford: Oxford University Press, 2009.

10. Porter M. Competitive strategy: Methodology of analyses of branches and competitors. Moscow: Alpina Pablisher, 2011.

11. Porter M. International competition. (1993) Moscow: Iternational Relationships

12. Prahalad S., Hamel G. The Core Competence of the Corporation. Harvard Business Review, 1990, 3, pp. 79-91.

13. Prebish R. Peripheral capitalism: are there any alternatives? (1992) Moscow, ILA RAN.

14. Sustainable Development Goals. Food and Agricultural Organization of the United Nations [Official site]. URL: http://www.fao.org/post-2015-mdg/background/fao-and-post2015/food-security/ru/ (accessed: 24.04.2017). 